DOI: 10.46340/eujem.2021.7.3.3

\title{
Viktoriya Mysyk
}

ORCID ID: https://orcid.org/0000-0001-8611-329X

Lviv Polytechnic National University, Ukraine

\section{METHODICAL APPROACHES TO DIAGNOSING PROCESSES OF EVENT MANAGEMENT FORMATION AND DEVELOPMENT}

The article considers the methodical approaches to diagnosing the processes of formation and development of event management at enterprises. It highlights and substantiates the possibility of using in this area such approaches as system, elemental, structural, functional, project and software ones. The basic methods of diagnosis of the formation and development of event management are statistical methods, matrix methods, indicator methods, expert methods, methods of design analogies, graphoanalytical methods and combined methods. These methods allow managers to see the variability of diagnostic areas in event management systems, as well as to choose reasonably certain approaches depending on the goals, objectives, available resources and other constraints. It is identified that the key phases of diagnosing the processes of event management formation and development are the following: preparation phase, diagnosis phase for the current state of event management formation and development, action planning phase, diagnostic plan implementation phase, a phase of search and evaluation of alternative solutions, which arose in the process of formation and development of event management, and a phase of completion of diagnostic work.

The research formulates the key parameters of diagnosing event management processes, which comprehensively cover all its components. It forms and presents the model of connection of event management with the goals of management and reveals the peculiarities of strategic diagnostics of event management, in particular, the analysis of the gap between the strategic plan and the real capabilities of the business entity. The paper carries out the analysis of optimality of organizational structure of the enterprise and efficiency of activity of labor team from the position of event management. Simultaneously it describes features of diagnostics of business environment of the enterprise from the event management point of view, allocates possible risks which can arise in the process, considers and analyzes in details peculiarities of diagnosing the event industry of the region which have an undeniable influence on the formation and development of event management in enterprises. Based on the results of the study, proposals were formulated for further research in the direction of diagnosing the processes of formation and development of event management.

Keywords: event management, event, management, event industry, business tourism, MICE.

Problem statement. Rapid processes of development of science and technology, market instability, continuity of globalization economic processes and other circumstances necessitate the development and improvement of tools for diagnosing the processes of formation and development of event management. The problem is complicated by the fact that the processes that take place within the event management system are complex and diverse, so considering potential changes in the operating environment the use of adequate methods of their analysis and diagnosis allows businesses to identify their strengths and weaknesses, interpret the results obtained and develop options for effective management decisions in this area.

Analysis of the latest studies and publications. Various scientists and institutions have studied the implementation of event management in enterprises and the improvement of its existing tools. The greatest contribution to the development of event management was made by researchers such as R. Thomas ${ }^{1}$,

${ }^{1}$ Thomas, R. (2011). Business elites, universities and knowledge transfer in tourism. Tourism Management, 33 (3), 553-561. 
W. Stam ${ }^{1}$, W. Smith ${ }^{2}$, J. R. Silver ${ }^{3}$, D. Getz ${ }^{4}$, B. Aldebert ${ }^{5}$, R. J. Dang ${ }^{6}$, C. Longhi ${ }^{7}$ and others. However, the problem is that little attention is paid to the research of event management processes in theory and practice. Some developments in the scientific literature (I. Kopytova, M. Golovan, O. Gavshyna, I. Markina and others) relate to the diagnosis and evaluation of management processes in general. Many of these suggestions can be used in the diagnosis process of the formation and development of event-management enterprises.

Research purpose. The purpose of the article is to consider methodological approaches to diagnosing the processes of formation and development of event management.

Presentation of the main research material. The study of theory and practice allows us to conclude that it is possible to diagnose the processes of event management in enterprises using different approaches (Table 1).

Table 1

Basic approaches to diagnosing event management

\begin{tabular}{|c|l|l|}
\hline № & \multicolumn{1}{|c|}{ Approaches } & \multicolumn{1}{c|}{ Characteristics of approaches } \\
\hline 1. & System approach & $\begin{array}{l}\text { This approach is based on the study of mechanisms of management and self- } \\
\text { management of a wide range of processes that are typical to management. }\end{array}$ \\
\hline 2. & Elemental approach & $\begin{array}{l}\text { The basis of this approach is to identify a number of elements that ensure the } \\
\text { construction of an event management system, and their interaction forms the } \\
\text { characteristics of the system and its properties. }\end{array}$ \\
\hline 3. & Structural approach & $\begin{array}{l}\text { The approach involves the study of the functional decomposition of the } \\
\text { structural components of event management, their properties and characteristics, } \\
\text { considering the stability of the relations between the components. }\end{array}$ \\
\hline 4. & Functional approach & $\begin{array}{l}\text { The emphasis in this approach is on identifying the functional relationship } \\
\text { between the constituent elements of event management and the management } \\
\text { system as a whole. }\end{array}$ \\
\hline 5. & Project approach & $\begin{array}{l}\text { Diagnosis by this approach is carried out through the analysis of the interaction } \\
\text { of event management with a neutral external element, which becomes possible } \\
\text { by creating a so-called projection of further reactions. }\end{array}$ \\
\hline 6. & Software approach & $\begin{array}{l}\text { The approach involves identifying the compliance of event management and its } \\
\text { processes to the previously created program of action. }\end{array}$ \\
\hline
\end{tabular}

Source: Developed by the authors on the basis of ${ }^{8}$

Diagnosis of event management processes can be carried out by various formal and informal methods. For better visual representation and simplified understanding, such methods as statistical, matrix, indicator, expert, methods of design analogies, graphoanalytical and combined methods should be distinguished (Table 2).

\footnotetext{
${ }^{1}$ Stam, W. (2010). Industry event participation and network brokerage among entrepreneurial ventures. Journal of Management Studies, 47, 625-653.

${ }^{2}$ Smith, W., (2008). Professional Meeting Management: Comprehensive Strategies for Meetings, Conventions and Events (5th edition). International Journal of Contemporary Hospitality Management, 20 (2), 237-238. DOI: https://doi.org/10.1108/09596110810852221.

${ }^{3}$ Silvers, J. R. (2009). Risk management for meetings and events. Oxford.

${ }^{4}$ Getz, D. (2012). Event studies. Theory, research and policy for planned events (2nd ed.). London. Oxford: Butterworth-Heinemann.

${ }^{5}$ Aldebert, B., Dang, R. J., Longhi, C. (2011). Innovation in the tourism industry: The case of tourism.

Tourism Management, 32(5), 1204-1213.

${ }^{6}$ Same as previous.

${ }^{7}$ Same as previous.

${ }^{8}$ Кузьмін О., Мельник О., Бондарецька О., Жежуха В. (2020). Мотивування персоналу підприємств: інновачійні технології та реінжинірингові підходи. Львів: Галицька видавнича спілка; Kuzmin O., Ovcharuk V., Zhezhukha V., Mehta D., Gregus J. (2020) Diagnosing the Administration Systems as a Prerequisite for Enterprises Business Processes Reengineering. In: Barolli L., Nishino H., Miwa H. (eds) Advances in Intelligent Networking and Collaborative Systems. INCoS 2019. Advances in Intelligent Systems and Computing, 1035. Springer, Cham, 513-524. DOI: https://doi.org/10.1007/978-3-030-29035-1_50.
} 
Basic methods of diagnostics of event management processes

\begin{tabular}{|c|c|c|}
\hline № & Methods & Characteristics of methods \\
\hline 1. & $\begin{array}{l}\text { Statistical } \\
\text { methods }\end{array}$ & $\begin{array}{l}\text { The methods are based on the construction of statistical models through the } \\
\text { collection, systematization and grouping of statistical material to analyze the } \\
\text { variation, dynamics and relationships of elements. These methods allow for point } \\
\text { and interval estimation, and are easy to implement due to the existence of a large } \\
\text { number of different software for calculations. This software can be easily adapted to } \\
\text { the needs of event management process diagnostics. }\end{array}$ \\
\hline 2. & Matrix methods & $\begin{array}{l}\text { Methods based on matrix and linear algebra, are used through the construction of } \\
\text { matrices with coefficients and indicators, designed to study complex large-scale } \\
\text { structures at the enterprise (associations) level and at the industry level. They allow a } \\
\text { fairly systematic approach to the diagnosis of event management due to the } \\
\text { orderliness of the components of the matrix and the clarity of the relationship } \\
\text { between them. }\end{array}$ \\
\hline 3. & $\begin{array}{l}\text { Indicator } \\
\text { methods }\end{array}$ & $\begin{array}{l}\text { The methods are consisting in the application of a system of indicators for the } \\
\text { purpose of integrated assessment of event management, advantages and } \\
\text { disadvantages of its application, as well as analysis of its processes and related } \\
\text { phenomena. Event management diagnosis indicators can include a wide variety of } \\
\text { indicators for a comprehensive assessment of its parameters. However, there is a } \\
\text { difficulty in choosing a specific indicator that will best meet the established } \\
\text { requirements. }\end{array}$ \\
\hline 4. & Expert methods & $\begin{array}{l}\text { They are included in the methods of scientific and technical forecasting and are } \\
\text { based on giving a certain circle of experts the opportunity to generate an adequate } \\
\text { model in a particular area with estimates of individual factors in the construction and } \\
\text { usage of event management. These estimates are, for the most part, quite subjective } \\
\text { and cannot be mathematically formalized due to the impossibility of quantitative } \\
\text { expression, and therefore cannot guarantee the full validity of judgments. }\end{array}$ \\
\hline 5. & $\begin{array}{l}\text { Methods of } \\
\text { design analogies }\end{array}$ & $\begin{array}{l}\text { The methods are based on the design of a number of properties of a particular object } \\
\text { to another object of study through a pre-established relationship of equivalence } \\
\text { between them, the laws of their behavior and functioning. Through the creation of an } \\
\text { analogue, they provide a quantitative assessment of processes and systems. }\end{array}$ \\
\hline 6. & $\begin{array}{l}\text { Graphoanalytical } \\
\text { methods }\end{array}$ & $\begin{array}{l}\text { These methods focus on the construction of geometric images and graphical figures } \\
\text { using the required number of vectors with a specific set of indicators. They allow to } \\
\text { visualize for better observation and analysis the weaknesses and strengths of the } \\
\text { processes in a series of figures. There is a difficulty in the functional separation of } \\
\text { certain processes and the possibility of evaluation problems in the case of a large } \\
\text { number of generated vectors. }\end{array}$ \\
\hline 7. & $\begin{array}{l}\text { Combined } \\
\text { methods }\end{array}$ & $\begin{array}{l}\text { These methods combine several groups of different methods or their individual } \\
\text { structural units. There is a difficulty in systematizing and comparing the results of } \\
\text { analysis and evaluation obtained in the process of using different types of not quite } \\
\text { related methods. However, in turn, such methods can provide a greater variation of } \\
\text { diverse and multifaceted combinations of quantitative and qualitative assessments. }\end{array}$ \\
\hline
\end{tabular}

Source: Developed by the authors on the basis of ${ }^{1}$

The methods given in Table 2 allow understanding exactly how it is possible to evaluate the processes of event management, and which options the company can choose depending on the situation.

\footnotetext{
${ }^{1}$ Kaczor, S., Kryvinska, N. (2013). It is all about Services - Fundamentals, Drivers, and Business Models. The Society of Service Science, Journal of Service Science Research, Springer, 5 (2), 125-154; Кузьмін, О., Мельник, О., Бондарецька, О., Жежуха, В. (2020). Мотивування персоналу підприємств: інновачійні технології та реінжинірингові підходи. Львів: Галицька видавнича спілка; Kryvinska, N. (2012). Building Consistent Formal Specification for the Service Enterprise Agility Foundation. The Society of Service Science, Journal of Service Science Research, Springer, 4 (2), 235-269.
} 
When diagnosing the processes of formation and development of event management, it is advisable to identify a number of key phases of this: 1) preparation phase; 2) diagnosis phase for the current state of event management formation and development; 3 ) action planning phase; 4) diagnostic plan implementation phase; 5 ) the phase of search and evaluation of alternative solutions, which arose in the process of formation and development of event management; 6) the phase of completion of diagnostic work.

The preparation phase includes the formation of an expert group that will carry out the diagnosis and on which the effectiveness of all further steps depends. This group will also select the information base to be used in the future. Diagnosis involves a clear formulation of the current diagnosis of the processes of formation and development of event management, considering all possible factors and features of the process today. The action planning phase includes the choice of methods and techniques for diagnosis, as well as step-by-step planning of all operations. In the fourth phase, the implementation of pre-planned actions to achieve the goal of diagnosis is done. The next phase involves finding and evaluating alternative solutions to the problem. The effectiveness of the whole diagnosis process depends on this phase. The diagnosis is completed by summarizing and structuring the results, as well as the design of reporting documentation.

- Event management can be diagnosed in different directions and according to different parameters. Among the key parameters of such a diagnosis there are the following:

- diagnosing the connection of event management with management goals;

- diagnosing the effectiveness of the event management strategy;

- diagnosing resource management of event management;

- assessment of the optimality of the organizational structure of the enterprise from the standpoint of event management;

- diagnosing the competence of managers in the formation and development of event management;

- diagnosing the processes of training and development of personnel on event management;

- diagnosing the level of satisfaction of participants with event management;

- diagnosing the financial aspects of event management;

- assessing the attractiveness of the business environment of the enterprise from the standpoint of event management;

- diagnosing the risks of the internal and external environment from the position of event management;

- diagnosing the state of the event industry in the region and its impact on the formation and development of event management of the business entity and other aspects.

Let us look through some parameters of diagnosing event management processes more carefully.

It is worth noting that from the standpoint of event management between the level of goals of a particular enterprise and the means to achieve those goals, there is a certain measure, which can be taken into account to ensure optimal and rational construction of parameters and implementation of all processes within event management. If you diagnose event management from the position of each individual element of the management system, it will certainly help achieve the goals of such a system as a whole.

Fig. 1. presents a model of communication of event management with different management goals and clearly outlines how from the position of enterprise development to structure, diagnose, analyze, evaluate, forecast and model the contribution of event management in achieving goals for each element of the management system on all its stages comprehensively.

In this context, it should be emphasized that ensuring a high level of efficiency of event management should not always be considered as an independent goal, but rather as one of the tools to promote efficiency of production and economic activity of a particular entity in general and improve its varies financial and economic performance.

Strategic diagnostics of event management contributes to the qualitative assessment of the effectiveness of the company's strategy, understanding strategic position based on each of its activities, thorough assessment of signals coming directly from the external and internal environments, obtaining diverse information that supports the company's management in the process of forming current goals and objectives. Strategic diagnostics of event management is aimed at finding answers to questions:

- whether the chosen event management strategy is correct and to what extent;

- the extent to which the event management strategy reflects the target guidelines of the enterprise;

- the extent to which the event management strategy corresponds to the conditions in which the company operates, in particular the situation in the external and internal environment. 


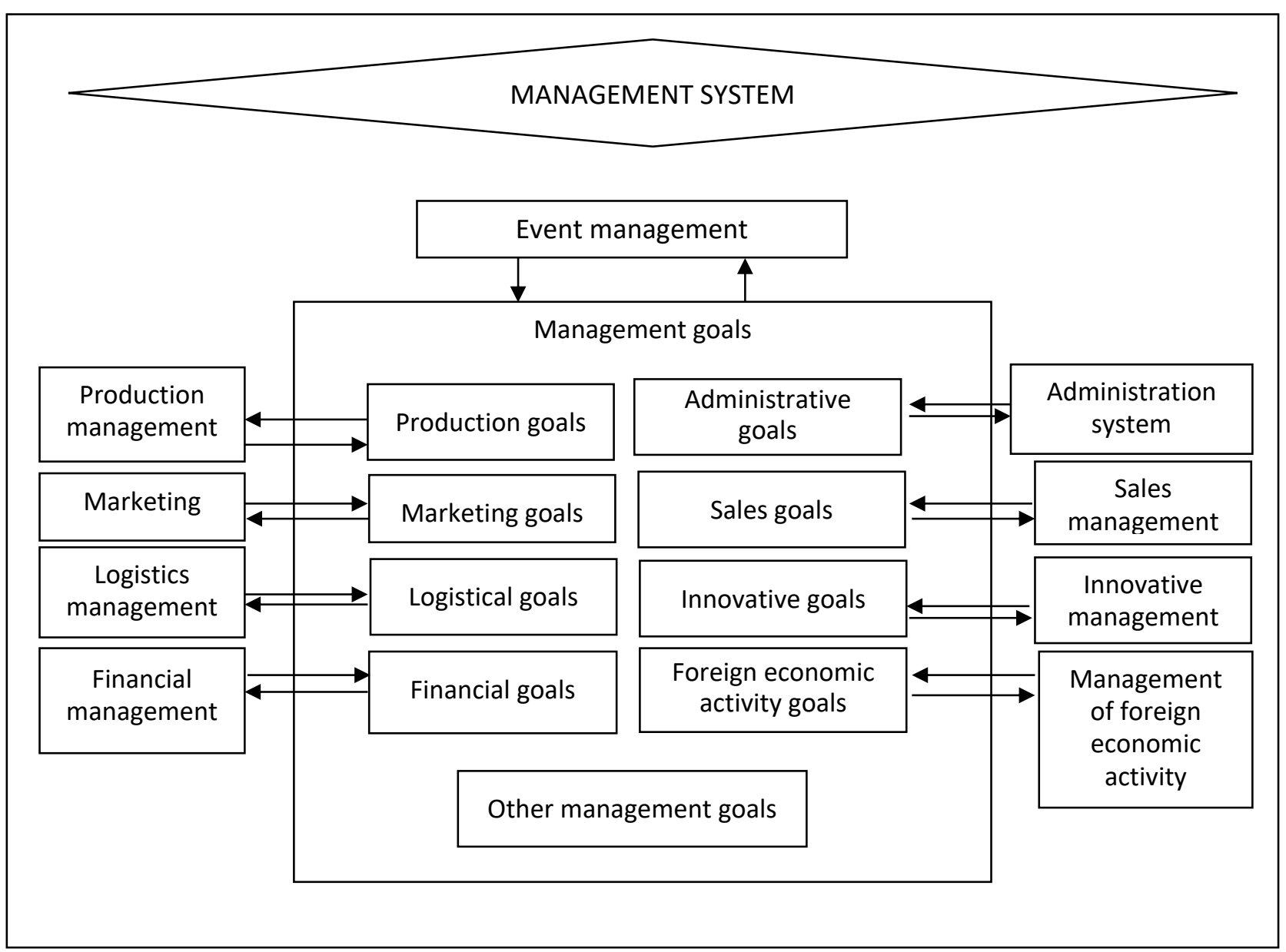

Fig. 1. Model of connection of event management with the goals of management

\section{Source: suggested by the author}

Event management largely provides support for the main activities of the enterprise (if the object of the main activity is not the event itself), and therefore the strategy of event management should be consistent with the overall strategy of the enterprise and its needs. The effectiveness of the event management strategy can be assessed as an option by analyzing the gap between the strategic plan and the real capabilities of the entity ${ }^{1}$. This method includes the following steps:

- establishing the real current capabilities of the enterprise;

- determination of the priority indicator of the enterprise activity on which the strategy is based;

- formation of a system of specific indicators of the strategic plan in accordance with the main interests of the business entity;

- establishing the desired trends in each specific indicator of the strategic plan;

- determining the difference between specific indicators of the strategic plan and the real capabilities of enterprises.

Another much faster way to assess the gap between a strategic plan and the real capabilities of the entity can be to distinguish between the most optimistic forecast and the most pessimistic expectations.

Diagnosing the resource management of event management includes assessing the volume and efficiency of use of enterprise resources involved in this area, their analysis, forecasting future costs for these processes and more.

\footnotetext{
${ }^{1}$ Маркіна, І. А., Таран-Лала, О. М., Гунченко, В. М. (2013). Контролінг для менеджерів: навчальний підручник. Київ: Центр навчальної літератури.
} 
One of the most important elements of resource management of event management is its information support. Among the main information sources necessary to diagnose the processes of formation and development of event management, it is appropriate to highlight the following:

- internal reporting of the enterprise (accounting, management and other spheres) and audit reports;

- various public information on the Internet (for example, company websites, information from social networks, statistics, electronic articles, reviews and others);

- results of marketing research and competitive analysis, information from the media, scientific publications;

- official correspondence with public authorities, partners and consumers;

- agreements of civil law and other nature;

- legal framework.

Assessing the optimality of the organizational structure of the enterprise from the viewpoint of event management, shows, in particular, the rationality of assigning certain work within the event management to staff and line units of the company, the effectiveness of establishing authority and responsibilities of jobs in this area, defining and enshrining job descriptions of event management employees.

In this context, I. Kopytova ${ }^{1}$ notes that one of the key problems in evaluating the effectiveness and efficiency of management systems is to determine a generally accepted system of criteria and indicators that will provide an objective and comprehensive assessment. Therefore, it is obvious that the complexity of forming a system of necessary indicators and criteria for assessing the optimal organizational structure of the enterprise on event management is also due to the specifics of the management system in general, because this system of criteria and indicators should, while summarizing all data, reproduce the model of quantitative and qualitative certainty of event management.

The optimal organizational structure of the enterprise in terms of event management should fully take into account the goals and objectives of the business, subject to the main activities of the entity. Considering the results of research by I. Kopytova ${ }^{2}$, it is possible to propose to assess the optimality of the organizational structure of the enterprise on event management in several areas:

- efficiency of the current organizational structure of event management;

- compliance of the existing organizational structure of event management with the chosen strategy of the enterprise;

- correct ranking of the tasks of the future strategy from the standpoint of event management between the units of the organization and its levels.

To date, there is no clearly algorithmic model that would ensure a comprehensive and complete implementation of certain areas of assessing the optimality of the organizational structure of management, therefore, this area has a wide field for research.

When diagnosing the processes of formation and development of event management, it is also appropriate to pay attention to the personal and professional competence of employees of the unit engaged in event management, because it is due to the high level of such competence effective management of business and team building activities is provided. It is appropriate to note that in the literature the concept of "competence" is considered differently. As an example, in his article M. Golovan ${ }^{3}$ interprets this concept as "possession of competence, which is manifested in effective activity and includes a personal attitude to the subject and product of activity; is an integrative formation of personality, which includes skills, knowledge, experience, as well as a system of personal qualities that determine the ability, desire and willingness of the individual to solve problems and tasks in real life situations, while realizing the importance of the subject and result".

In order to increase the efficiency of the business entity's activity, it is important to constantly improve the quality of performance of official duties by employees, work process, efficiency of task performance, as well as increase staff motivation. Training and development of employees is both a motivational component of activity and a direct component of improving the operational process. Diagnosing the processes of training and development of event management personnel is necessary to assess the quality of these processes, find options for their optimization, identify deviations and opportunities for the application of innovative

\footnotetext{
${ }^{1}$ Копитова, І. В. (2014). Оцінка оптимальності організаційної структури управління при зміні стратегії підприємства. Ефективна економіка, 5. <http://nbuv.gov.ua/UJRN/efek_2014_5_80> (2021, лютий, 25).

2 Там само.

${ }^{3}$ Голован, М. С. (2008). Компетенція і компетентність: досвід теорії, теорія досвіду. Вища освіта Украӥни, 3 , 23-30.
} 
components, use modern approaches to business and team building activities in the organization and compare them with the experience of other event market participants.

Existence of opportunities for continuous training and development of personnel at the enterprise, including in the field of event management, is a requirement of modern society, and ignoring the fact can lead to many problems in the future. The HPPY ${ }^{1}$ business portal notes that continuing professional training includes providing employees with opportunities to improve their skills and obtain the necessary level of education that will increase their efficiency and contribute to the achievement of the organization's goals. Such programs are usually funded in whole or partly by the company, giving the employee an additional incentive for productive work, because the knowledge gained is an investment in the future of both the individual employee and the company as a whole.

Diagnosing the processes of training and development of employees includes analysis of all training programs of the enterprise, additional development opportunities for staff, courses and trainings attended by employees, the effectiveness of these courses, the ratio of "price-quality-benefit". It also includes an assessment of development opportunities within the position and career prospects, analysis of staff motivation, diagnosing investment in staff training. The information obtained in the process of such diagnostics is necessary to determine future plans and strategies for staff development, likewise to identify ineffective methods, problem areas and deviations in current curricula and plans.

Diagnosing the level of employee satisfaction with event management in the company, first of all, is to determine whether staff understands the specifics of this type of management and its place in the management system as a whole, whether employees are satisfied with what event management contributes to the company's life and how to assess such a contribution, whether the staff understands their tasks within the event management.

Event management is a fairly new type of management activity, so often employees who are unfamiliar with its tools and features, may be opposed to innovations in this area. Under such conditions, the main thing is to quickly notice contradictions in opinions and views, find common ground, explain to employees the specifics of event management, the benefits of its operation, as well as the benefits for the company. Another situation arises when the company itself first encounters the introduction of event management or its individual elements, involving already experienced experts in this field. Such an assessment of satisfaction by more qualified event managers as external experts will help to determine whether this process is moving in the right direction.

No less important is the diagnosis of the financial condition of the enterprise and, in particular, the financial aspects of event management. O. Gavshina and I. Tarasenko in their scientific work ${ }^{2}$ according $^{2}$ to the degree of validity distinguish two methods of diagnosing the financial condition and its individual financial aspects, namely - formalized and informal. Formalized methods of diagnosis are scientifically sound and analytically proven, furthermore due to their high objectivity popular in the practice of assessment among Ukrainian enterprises. Informal methods, unlike formalized ones, characterize analytical procedures not on rigid analytical interdependencies and connections, but rather on a logical level, are more subjective, because they are based on the intuition, experience and general knowledge of the person performing the analysis.

Diagnosis of the financial aspects of event management begins with the analysis of the financial statements of the enterprise and directly the reports relating to the event component of the entity. The result of such diagnostics is to obtain a number of key informative parameters for objective and accurate reflection of the impact of the event component on the overall financial condition of the enterprise. The obtained data are used in the formation of enterprise development plans and event management strategies.

Diagnosing the risks of the internal and external environment and assessing its attractiveness from the standpoint of event management can also be done using a variety of methodological approaches. In particular, the strengths and weaknesses of the organization are often assessed in practice in this direction, along with the chances and threats of the environment, the attractiveness of the existing market and prospects for its development is diagnosed, the impact of the environment on event management in the enterprise and the market is analyzed.

\footnotetext{
${ }^{1}$ HPPY (2021). Continuous education and development for employees - learning in the workplace $<$ https://gethppy.com/talent-management/continuous-education-and-development> (2021, March, 01)

${ }^{2}$ Гавшина, O. I., Тарасенко, I. О. (2015) Діагностика фінансового стану в системі управління економічною безпекою підприємства. Міжнародний науковий журнал, 8, 104-107.
} 
Threats to the development of event management in the context of an individual entity may be:

- negative socio-political changes;

- inflation;

- adverse changes in legislation;

- tendencies to economic decline;

- reduction of the pace of development of science and technology in the country, as well as technological breakthroughs in other countries, which reduce the competitiveness of the enterprise in the world market.

At the same time, the business environment can be characterized by attractiveness for event management and opportunities for its development. This occurs when:

- there is socio-political stability;

- there are scientific and technical breakthroughs in the country;

- there is rapid development of the event industry and event market;

- there are favorable changes in the legislation;

- there are tendencies to economic development;

- innovations are introduced in event management and in the event market.

A comprehensive analysis of the external environment provides a solid foundation for a high-quality and simplified selection of an effective strategy for future market actions and verification of the existing strategy for compliance with environmental requirements.

Diagnosing the state of the event industry in the region and its capabilities for the formation and development of event management should be carried out by comparing the event industry of several regions. This will allow you to clearly see the strengths and weaknesses of the region, along with its opportunities and threats. Today we should not forget that the event market has also spread to the online virtual environment. This creates a lot of opportunities for businesses, but at the same time there is a much stronger global competition.

Therefore, when diagnosing the state of the event industry in the region, it is necessary to analyze carefully such factors as:

- opportunities for conducting online events in the region;

- availability and number of existing online platforms to promote their events and participate in events of neighboring companies for training and development;

- the number of large-scale one-off events held in the region;

- the number of permanent seasonal events in the region;

- assessment of the regional activities by scale (number of people visited, budget, etc.);

- marketing campaigns for events in the region and neighboring companies, assessment of opportunities and reactions of the audience;

- the main providers of events in the regional event industry;

- the main consumers of event services in the region;

- promotion of the legislation of the region of event industry development;

- the level of scientific and technological progress and innovation in the region;

- availability of quality information channels;

- availability of specific territorial opportunities;

- socio-political situation;

- economic situation of the region;

- infrastructure of the region;

- cultural features that create new opportunities for the development of the event industry;

- the level of experience of representatives of the event industry;

- the market size and other factors.

We should also not forget the importance of comparing the event industry of the particular region to the industry of world events in general.

Marketing research platform $\mathrm{AMR}^{1}$ offers to analyze the world event industry, segmenting it based on the type of event, source of income, organizers, age group of participants and the region. Depending on the type, the industry is divided into world-class exhibitions and conferences, international festivals, world-class corporate events and seminars, music concerts, global sporting events and more. According to the source

\footnotetext{
${ }^{1}$ Allied Market Research (2021). Global Opportunity Analysis and Industry Forecast, 2019-2026.

<https://www.alliedmarketresearch.com/events-industry-market> (2021, March, 02).
} 
of income, there is the divisions of income from ticket sales, sponsorship and others. Based on the classification of event organizers, the industry is divided into global corporate component, sports, education, entertainment and others. By age group, the industry is divided into stakeholders under the age of 20, from 21 to 40 years and 41 years and older. Evaluation and analysis of all these categories will help determine the position of the enterprise in the segment of the event industry.

Conclusions. In summary, it should be noted that diagnosing the processes of formation and development of event management in each of mentioned areas is necessary and practically significant, therefore, requires further research. At the same time, the study of theory and practice allows us to conclude that today the highest priority should still be considered to analyze the level of formation of event management in the enterprise. After determination of the specific level of such formation, it is possible to clearly see in which direction it is necessary to move in the process of formation of event management or improvement of its existing elements.

\section{References:}

1. Aldebert, B., Dang, R. J., Longhi, C. (2011). Innovation in the tourism industry: The case of tourism. Tourism Management, 32(5), 1204-1213. [in English].

2. HPPY (2021). Continuous education and development for employees - learning in the workplace. $<$ https://gethppy.com/talent-management/continuous-education-and-development> (2021, March, 01) [in English].

3. Gavshyna, O. I., Tarasenko, I. O. (2015). Diagnostyka finansovogo stanu v systemi upravlinnya ekonomichnoyu bezpekoyu pidpryyemstva [Diagnosis of financial condition in the management system of economic security of the enterprise]. Mizhnarodnyj naukovyj zhurnal [International scientific journal], 8, 104-107. [in Ukrainian].

4. Getz, D. (2012). Event studies. Theory, research and policy for planned events. London. Oxford: Butterworth-Heinemann. [in English].

5. Allied Market Research (2021). Global Opportunity Analysis and Industry Forecast, 2019-2026. <https://www.alliedmarketresearch.com/events-industry-market> (2021, March, 02). [in English].

6. Golovan, M. S. (2008). Kompetenciya I kompetentnist: dosvid teoriyi, teoriya dosvidu [The competence and expertise: experience theory, the theory of experience]. Vyscha osvita Ukrayiny [Ukrainian higher education], 3, 23-30. [in Ukrainian].

7. Kaczor, S., Kryvinska, N. (2013). It is all about Services - Fundamentals, Drivers, and Business Models. The Society of Service Science, Journal of Service Science Research, Springer, 5 (2), 125-154. [in English].

8. Kopytova, I. V. (2014). Ocinka optymalnosti organizacijnoyi struktury upravlinnya pry zmini strategiyi pidpryyemstva [Estimation of optimality of organizational structure of management at change of strategy of the enterprise]. Efektyvna ekonomika, 5. <http://nbuv.gov.ua/UJRN/efek_2014_5_80> (2021, February, 25). [in Ukrainian].

9. Kryvinska, N. (2012). Building Consistent Formal Specification for the Service Enterprise Agility Foundation. The Society of Service Science, Journal of Service Science Research, Springer, 4 (2), 235-269. [in English].

10. Kuzmin, O., Ovcharuk, V., Zhezhukha, V., Mehta, D., Gregus, J. (2020). Diagnosing the Administration Systems as a Prerequisite for Enterprises Business Processes Reengineering. [In:] Barolli, L., Nishino, H., Miwa, H. (eds.) Advances in Intelligent Networking and Collaborative Systems. INCoS 2019. Advances in Intelligent Systems and Computing, vol. 1035. Springer, Cham, 513-524. DOI: https://doi.org/10.1007/978-3-030-29035-1_50 [in English].

11. Kuzmin, O., Melnyk, O., Bondarecka, O., Zhezhukha, V. (2020). Motyvuvannya personal pidpryyemstv: innovacijni tehnologiyi ta reinzhyniryngovi pidhody [Motivation of enterprise personnel: innovative technologies and reengineering approaches]. Lviv: Galytska vydavnycha spilka. [in Ukrainian].

12. Markina, I. A., Taran-Lala, O. M., Gunchenko, V. M. (2013). Kontroling dlya menedzheriv: navchalnyj posibnyk [Controlling for managers: the manual]. Kyiv: Centr navchalnoyi literatury. [in Ukrainian].

13. Silvers, J. R. (2009): Risk management for meetings and events. Oxford. [in English].

14. Smith, W. (2008). Professional Meeting Management: Comprehensive Strategies for Meetings, Conventions and Events. International Journal of Contemporary Hospitality Management, 20 (2), 237-238. DOI:https://doi.org/10.1108/09596110810852221. [in English].

15. Stam, W. (2010). Industry event participation and network brokerage among entrepreneurial ventures. Journal of Management Studies, 47, 625-653. [in English].

16. Thomas, R. (2011). Business elites, universities and knowledge transfer in tourism. Tourism Management, 33 (3), 553-561. [in English].

17. Ugolkov, I., Karyy, O., Skybinskyi, O., Ugolkova, O., Zhezhukha, V. (2020). The evaluation of content effectiveness within online and offline marketing communications of an enterprise. Innovative Marketing, 16 (3), 26-36. DOI:10.21511/im.16(3).2020.03. [in English]. 